\title{
Effectiveness of Marketing Techniques Adhered Athenova Technologies
}

\author{
M. Anbarasi, S. Praveen Kumar
}

\begin{abstract}
The reason for this examination is to survey the connection between adequacy of showcasing procedures execution Marketing branches. This exploration as far as reason for existing is connected; and furthermore as far as technique is distinct correlational research and in term of span is a solitary period. To pick the factual example by utilizing old style arbitrary inspecting and as per the measurable equation, an example of individuals is chosen from among the factual populace. As indicated by research system and the kind of the fundamental information in this examination, survey of standard advertising techniques and scientist promoting execution are utilized as the primary instrument to quantify and information gathering. So as to do the measurable examination, SPSS factual investigation programming is utilized.
\end{abstract}

Keywords: Effectiveness of marketing strategies, Performance marketing

\section{INTRODUCTION}

The specialist has attempted this investigation with the accompanying points and goals. To study the common administration approaches and methodologies embraced by instructive foundations giving administration training in the current worldwide situation. [1],[3],[5].To break down the advertising blend procedures methodologies utilized by instructive establishments conferring the board training. To basically study the brand building, brand situating, and brand maintainability systems embraced by these administration foundations covering their different partners. To study the achievability and possibility of promoting endeavors of the executives foundations with respect to advertising arranging, showcase division, client relationship the board and working of brand unwaveringness among them. To relatively examine the brand situating status and the possibility of the instructive organizations secured under the examination to in the long run create worldwide brand initiative[2 ],[4],[6]

Revised Manuscript Received on July 22, 2019

M. Anbarasi, Department of MBA, Bharath Institute of Higher Education and Research, Chennai, India. Email: praveenkumar.mba@bharathuniv.ac.in

Dr. S. Praveen Kumar, Department of MBA, Bharath Institute of Higher Education and Research, Chennai, India. Email: praveenkumar.mba@bharathuniv.ac.in

\section{ANALYSIS}

Table 1 - Not Given an Opportunity to tell my side of story

\begin{tabular}{|l|l|l|}
\hline \multicolumn{1}{|c|}{ PARTICULARS } & FREQUENCY & PERCENTAGE \\
\hline Strongly disagree & 4 & 3.8 \\
\hline Disagree & 15 & 14.3 \\
\hline Neutral & 25 & 23.8 \\
\hline Agree & 36 & 34.3 \\
\hline Strongly agree & 25 & 23.8 \\
\hline Total & $\mathbf{1 0 5}$ & $\mathbf{1 0 0}$ \\
\hline
\end{tabular}

Figure 1 - Not Given an Opportunity to tell my side of story

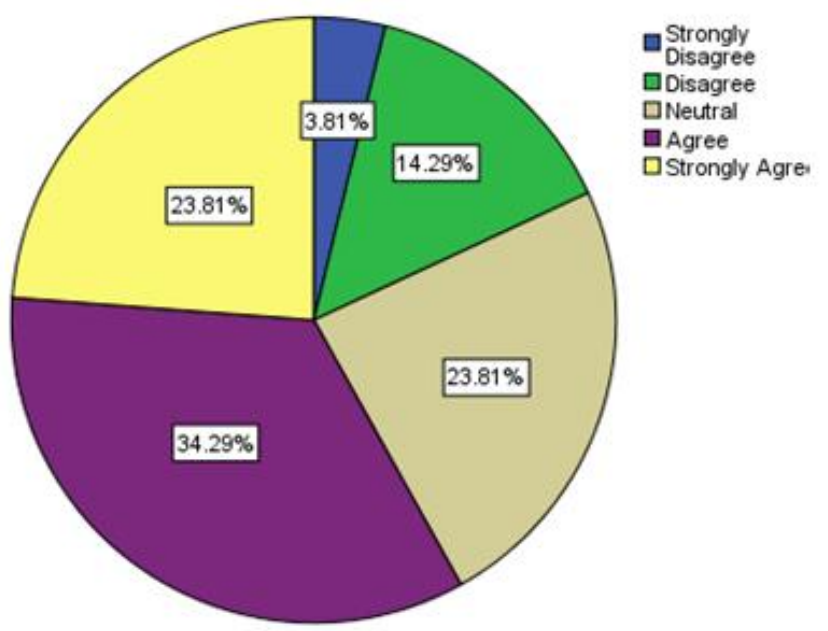

Inference:

It can be seen from Table 4.14 that $3.8 \%$ of the respondents rated strongly disagree; $14.3 \%$ of the respondents rateddisagree; $23.8 \%$ of the respondent are rated neutral, $34.3 \%$ of the respondents are rated agree; andremaining $23.8 \%$ of the respondents rated strongly agree.

Table2 - The service provider has fair policies and procedures for dealing with customer

\begin{tabular}{|l|l|l|}
\hline \multicolumn{1}{|c|}{ PARTICULARS } & FREQUENCY & PERCENTAGE \\
\hline Strongly disagree & 1 & 1.0 \\
\hline Disagree & 13 & 12.4 \\
\hline Neutral & 24 & 22.9 \\
\hline Agree & 35 & 33.3 \\
\hline Strongly agree & 32 & 30.5 \\
\hline Total & 105 & 100 \\
\hline & \multicolumn{2}{|c|}{ Published By: } \\
Blue Eyes Intelligence Engineering \\
\& Sciences Publication
\end{tabular}




\section{Effectiveness of Marketing Techniques Adhered Athenova Technologies}

Figure2 - The service provider has fair policies and procedures for dealing with customer

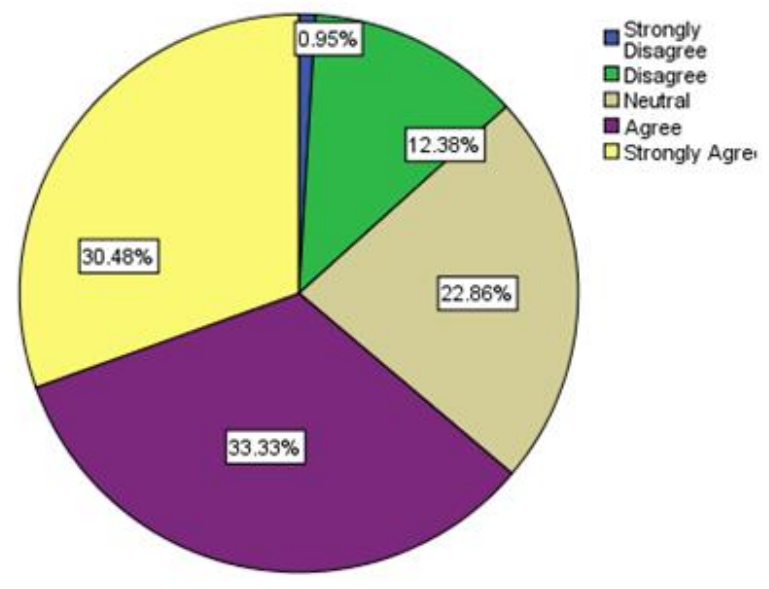

\section{Inference:}

It can be seen from Table 4.15 that $1 \%$ of the respondents rated strongly disagree; $12.4 \%$ of the respondents rateddisagree; $22.9 \%$ of the respondent are rated neutral, $33.3 \%$ of the respondents are rated agree; andremaining $30.5 \%$ of the respondents rated strongly agree

Table 3 - Company staff was honest in dealing with my complaints

\begin{tabular}{|l|l|l|}
\hline \multicolumn{1}{|c|}{ PARTICULARS } & FREQUENCY & PERCENTAGE \\
\hline Strongly disagree & 5 & 4.8 \\
\hline Disagree & 7 & 6.7 \\
\hline Neutral & 26 & 24.8 \\
\hline Agree & 43 & 41.0 \\
\hline Strongly agree & 24 & 22.9 \\
\hline Total & $\mathbf{1 0 5}$ & $\mathbf{1 0 0}$ \\
\hline
\end{tabular}

Figure 3 - Company staff was honest in dealing with my complaints

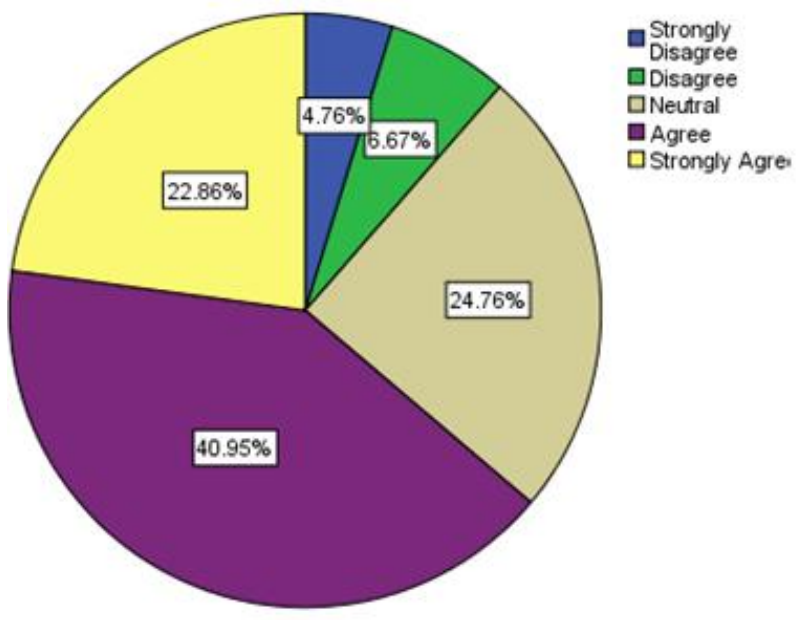

\section{Inference:}

It can be seen from Table 4.16 that $4.8 \%$ of the respondents rated strongly disagree; $6.7 \%$ of the respondents rateddisagree; $24.8 \%$ of the respondent are rated neutral, $41 \%$ of the respondents are rated agree; andremaining $22.9 \%$ of the respondents rated strongly agree.
Table 4 - Satisfied with the way my problem was resolved

\begin{tabular}{|l|l|l|}
\hline \multicolumn{1}{|c|}{ PARTICULARS } & FREQUENCY & \multicolumn{1}{c|}{ PERCENTAGE } \\
\hline Strongly disagree & 9 & 8.6 \\
\hline Disagree & 11 & 10.5 \\
\hline Neutral & 22 & 21.0 \\
\hline Agree & 45 & 42.9 \\
\hline Strongly agree & 18 & 17.1 \\
\hline Total & $\mathbf{1 0 5}$ & $\mathbf{1 0 0}$ \\
\hline
\end{tabular}

Figure 4 - Satisfied with the way my problem was resolved

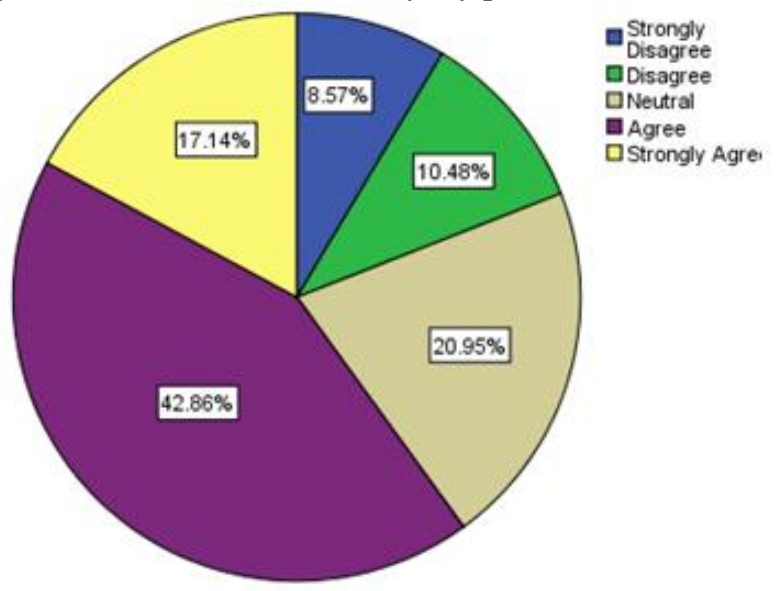

\section{Inference:}

It can be seen from Table 4.17 that $8.6 \%$ of the respondents rated strongly disagree; $10.5 \%$ of the respondents rateddisagree; $20 \%$ of the respondent are rated neutral, 42.9 $\%$ of the respondents are rated agree; andremaining $17.1 \%$ of the respondents rated strongly agree

Table 5 - Provide discounts

\begin{tabular}{|l|l|l|}
\hline \multicolumn{1}{|c|}{ PARTICULARS } & FREQUENCY & \multicolumn{1}{c|}{ PERCENTAGE } \\
\hline Strongly disagree & 8 & 7.6 \\
\hline Disagree & 18 & 17.1 \\
\hline Neutral & 38 & 36.2 \\
\hline Agree & 27 & 25.7 \\
\hline Strongly agree & 14 & 13.3 \\
\hline Total & $\mathbf{1 0 5}$ & $\mathbf{1 0 0}$ \\
\hline
\end{tabular}

Figure 5 - Provide discounts 


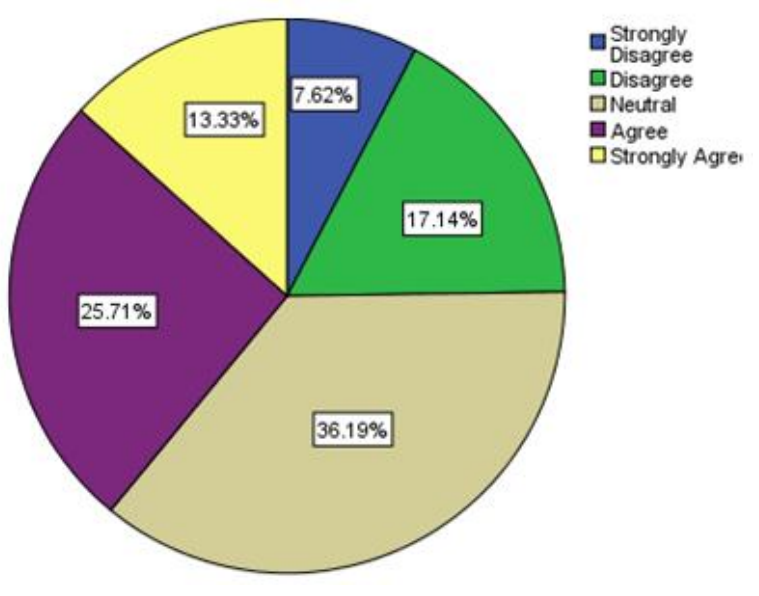

\section{Inference:}

It can be seen from Table 4.18that $7.6 \%$ of the respondents rated strongly disagree; $17.1 \%$ of the respondents rateddisagree; $36.2 \%$ of the respondent are rated neutral, $25.7 \%$ of the respondents are rated agree; andremaining $13.3 \%$ of the respondents rated strongly agree

\section{A. CHI-SQUARE TEST}

$\mathbf{H}_{\mathbf{0 . 1}}=$ There Is No Difference between Age and Income ofthe Respondents

\section{Chi-Square Tests}

\begin{tabular}{|l|l|l|l|}
\hline & Asymptotic \\
& Value & df & $\begin{array}{l}\text { Significance } \\
\text { (2-sided) }\end{array}$ \\
\hline $\begin{array}{l}\text { Pearson Chi-Square } \\
\text { Likelihood Ratio }\end{array}$ & $11.396^{\mathrm{a}}$ & 12 & .495 \\
Linear-by-Linear & 11.775 & 12 & .464 \\
Association & 2.208 & 1 & .137 \\
N of Valid Cases & 105 & & \\
\hline **Significant at 5\% level &
\end{tabular}

Result: It can be seen from Table 4.23 that the null hypothesis is accepted.

Discussion: The calculator value less then table value so There Is No Difference between age and income of the respondents.

\section{RESULTS}

1. $4.8 \%$ of the respondents evaluated Below 20 years; 11.4 $\%$ of the respondents appraised 21-30 years; $32.4 \%$ of the respondents evaluated 31-40 years; $36.2 \%$ of the respondents appraised 41-50 years and staying $15.2 \%$ of the respondents appraised over 50 years [7], [9],[11]

2. $59 \%$ of the respondents evaluated Male and remaining $41 \%$ of the respondents appraised female.

3. $4.8 \%$ of the respondents evaluated Business; $10.5 \%$ of the respondents appraised Professional; $28.6 \%$ of the respondents evaluated Government; $40 \%$ of the respondents appraised Private and staying $16.2 \%$ of the respondents appraised not working

4. $61.9 \%$ of the respondents evaluated underneath 15000 ; $30.5 \%$ of the respondents rated $15000-40000 ; 3.8 \%$ of the respondents appraised 40000-100000; and staying $3.8 \%$ of the respondents appraised over 100000. [8], [10],[12]

5. Married and staying $47.6 \%$ of the respondents evaluated single.

6. Product selling techniques; Advertisement $3.8 \%$ of the respondents appraised emphatically disagree;5.7 \% of the respondents rateddisagree; $13.3 \%$ of the respondent are evaluated neutral,49.5\% of the respondents are evaluated concur; andremaining $27.6 \%$ of the respondents appraised unequivocally concur

7. Best of Product selling techniques; Sale executive4.8\% of the respondents appraised emphatically disagree; $10.5 \%$ of the respondents rateddisagree; $19 \%$ of the respondent are evaluated neutral,33.3\% of the respondents are evaluated concur; andremaining $32.4 \%$ of the respondents appraised unequivocally concur

8. Best of Product selling techniques; Banners1\% of the respondents appraised emphatically disagree; $11.4 \%$ of the respondents rateddisagree; $18.1 \%$ of the respondent are evaluated neutral,45.7 \% of the respondents are evaluated concur; andremaining $23.8 \%$ of the respondents appraised unequivocally concur

9. Best of Product selling techniques; Notice $1 \%$ of the respondents appraised emphatically disagree;5.7 \% of the respondents rateddisagree; $27.6 \%$ of the respondent are evaluated unbiased, $37.1 \%$ of the respondents are appraised concur; andremaining $28.6 \%$ of the respondents appraised firmly concur [13], [15],[17]

10. Delivery of item is reliable $1.9 \%$ of the respondents appraised emphatically disagree;3.8 \% of the respondents rateddisagree; $17.1 \%$ of the respondent are evaluated unbiased, $52.4 \%$ of the respondents are appraised concur; andremaining $24.8 \%$ of the respondents appraised firmly concur.

11. A administration framework is clear and comprehend $6.7 \%$ of the respondents appraised emphatically disagree; 6.7 $\%$ of the respondents rateddisagree; $21.9 \%$ of the respondent are evaluated impartial, $42.9 \%$ of the respondents are evaluated concur; andremaining $21.9 \%$ of the respondents appraised unequivocally concur.

12. The item was quality $3.8 \%$ of the respondents appraised emphatically deviate; $12.4 \%$ of the 


\section{Effectiveness of Marketing Techniques Adhered Athenova Technologies}

respondents rateddisagree; $29.5 \%$ of the respondent are evaluated unbiased, $41.9 \%$ of the respondents are appraised concur; andremaining $12.4 \%$ of the respondents appraised firmly concur. [14], [16],[18]

13. The specialist co-op adjusted their grievance taking care of systems to fulfill my needs $4.8 \%$ of the respondents evaluated emphatically deviate; $10.5 \%$ of the respondents appraised dissent; $28.6 \%$ of the respondent are appraised impartial, $40 \%$ of the respondents are appraised concur; and staying $16.2 \%$ of the respondents appraised unequivocally concur.

14. Not allowed a chance to tell my side of STORY3.8 \% of the respondents appraised emphatically deviate; $14.3 \%$ of the respondents rateddisagree; $23.8 \%$ of the respondent are evaluated unbiased, $34.3 \%$ of the respondents are appraised concur; andremaining $23.8 \%$ of the respondents appraised firmly concur. [19], [21],[23]

15. The specialist co-op has reasonable arrangements and strategies for managing customer $1 \%$ of the respondents appraised firmly deviate; $12.4 \%$ of the respondents evaluated dissent; $22.9 \%$ of the respondent are evaluated impartial, $33.3 \%$ of the respondents are appraised concur; and staying $30.5 \%$ of the respondents appraised unequivocally concur.

16. Company staff was straightforward in managing my complaints $4.8 \%$ of the respondents appraised unequivocally dissent; $6.7 \%$ of the respondents evaluated deviate; $24.8 \%$ of the respondent are appraised nonpartisan, $41 \%$ of the respondents are appraised concur; and staying $22.9 \%$ of the respondents appraised firmly concur. [20], [22], [24]

17. Satisfied with the manner in which my concern was settled $8.6 \%$ of the respondents appraised unequivocally dissent; $10.5 \%$ of the respondents rateddisagree; $20 \%$ of the respondent are evaluated impartial, $42.9 \%$ of the respondents are appraised concur; andremaining $17.1 \%$ of the respondents appraised emphatically concur.

18. Provide discounts $7.6 \%$ of the respondents evaluated unequivocally deviate; $17.1 \%$ of the respondents rateddisagree; $36.2 \%$ of the respondent are appraised unbiased, $25.7 \%$ of the respondents are appraised concur; andremaining $13.3 \%$ of the respondents appraised firmly concur.

19. Annual compliment $4.8 \%$ of the respondents evaluated unequivocally deviate; $4.8 \%$ of the respondents rateddisagree; $30.5 \%$ of the respondent are appraised unbiased, $38.1 \%$ of the respondents are appraised concur; andremaining $21.9 \%$ of the respondents appraised firmly concur. [25], [27], [29]

20. Gift system $4.8 \%$ of the respondents evaluated unequivocally deviate; $5.7 \%$ of the respondents rateddisagree; $26.7 \%$ of the respondent are appraised unbiased, $48.6 \%$ of the respondents are appraised concur; andremaining $14.3 \%$ of the respondents appraised firmly concur.

21. Price separation for standard customers $10.5 \%$ of the respondents appraised unequivocally dissent; $23.8 \%$ of the respondents evaluated deviate; $21 \%$ of the respondent are evaluated impartial, $35.2 \%$ of the respondents are appraised concur; and staying $9.5 \%$ of the respondents evaluated firmly concur.

22. Price limits for references $1.9 \%$ of the respondents evaluated unequivocally deviate; $11.4 \%$ of the respondents appraised dissent; $28.6 \%$ of the respondent are appraised nonpartisan, $32.4 \%$ of the respondents are evaluated concur; and staying $25.7 \%$ of the respondents appraised emphatically concur.

\section{DISCUSSION}

I Understand the Customer Mindset and Adjust Practices Accordingly

2. Customer correspondence has changed as of late, however whatever the strategy, it is certain that picking up client trust is key for reps.

3. In internet based life, we utilize the $80 / 20$ rule: $80 \%$ of substance is taken into account the peruser with tips, stunts, and learning identified with our administration, while $20 \%$ is explicitly about our organization and what we are doing.

4. Establishing connections with clients as referenced above, yet with compelling friends is profitable too. Perhaps the greatest biological system is the Salesforce.com people group, so keeping current with this is an absolute necessity. Online networking is another significant field to ace - ideally LinkedIn and Twitter, where reps can progress toward becoming promoters of their work while interfacing with clients and accomplices. At last, it never damages to meet individuals the old style way first - in particular, face to face. At that point, you remain associated with them through their favored web based life stage.[26], [28], [30]

5. Successful promoting isn't just about driving whatever number new deals as would be prudent, yet rather creating and sustaining long haul connections dependent on trust that win you brand inclination, rehash business, and brand envoys.

6. It appears as though another online stage is being presented at regular intervals, which implies that your group of spectators may not be getting their news and data in similar spots they were only a brief timeframe back.

7. Improve your advertising, look to your rivals. Discover what 
they are doing to draw in clients.

8. People need to realize that they're burning through cash on quality. Furthermore, they need to know whether what you bring to the table is superior to what your rivals bring to the table.

\section{V.CONCLUSION}

Showcasing procedure is something that continually develops, adjusting to changing economic situations. Inside Enterprise, the results from its a wide range of kinds of business are always surveyed and assessed. Decisions are then bolstered into the basic leadership process. This empowered new techniques to be created to improve activities.

In any case, while procedures change, one part of the business has stayed set up. This is a proceeded with spotlight on large amounts of client administration and worker relations. This system has empowered Enterprise to appreciate proceeded with development for over 55 years and the possibility of further development later on. [31], [33]

As ages advance and innovation builds up, the progression in the field of showcasing and ads has been monstrous. Never again are organizations bound by the restrictions of conventional advertising systems. The old has been vigorously supplanted by the new. One of the freshest and best systems has been of web based promoting, which is the theme that this entire digital book was focused on. Web based advertising uses the web and its abundance of assets for limited time, profile-raising purposes.

Advancement is key component in promoting technique of a business concern. It is the way toward building up a correspondence framework to build up the corporate and 271 item picture among the center man. Its point is to convey the learning about the organization, its destinations, exercises, items, costs and strategies. The appropriation framework is to move a fixed item from the spot of assembling to the spot of utilization. Choices which are worried about issues, for example, move of dispersion system to be received, the expected market inclusion, the expense of transportation, commission and credit term for different center men comprise the general circulation strategy of an organization

\section{REFERENCES}

1) BharthVajan R., Ramachandran S.,Psychographic dimensions of training,2016,International Journal of Pharmacy and Technology,V-8,I-4,P-23727-23729

2) Balakrishnan P., Bharthvajan R.,A study on human resource planning in hospitals in Chennai City,2014,International Journal of Applied Engineering Research,V-9,I-22,P-7503-7507

3) Priyadarsini P., Bharthvajan R.,Role of emotional intelligence training programme in reducing the stress of the nurses,2014,International Journal of Applied Engineering Research,V-9,I-22,P-7411-7421

4) Kerinab Beenu G., Bharthvajan R.,Empirical analysis on the cosmetic buying behavior of young women in South India,2014,International Journal of Applied Engineering Research,V-9,I-22,P-7361-7366

5) Balakrishnan P., Bharthvajan R.,Whistling in the wind,2014,International Journal of Applied Engineering Research,V-9,I-22,P-7586-7593

6) Krishnan B., Peter M.,Health hazards of Indian Bpo employee-an alarming issue,2014,International Journal of Applied Engineering Research,V-9,I-22,P-7336-7341
7) Kerinab Beenu G.H., Peter M.,Role of insurance in economic development,2014,International Journal of Applied Engineering Research,V-9,I-22,P-7532-7539

8) Balakrishnan P., Peter M., Priyadarsini P.,Efficiency of safety measures for wellbeing of employees in manufacturing industry,2014,International Journal of Applied Engineering Research,V-9,I-22,P-7376-7382

9) Anbarasi M., Praveen Kumar S.,Online sales promotions of herbal products and its effectiveness towards tanisha.com,2019,Indian Journal of Public Health Research and Development,V-10,I-1,P-195-200

10) Anbarasi M., Praveen Kumar S.,Various online marketing and promotions strategies to improve the validation towards the organic products in the pharmaceutical sectors,2019,Indian Journal of Public Health Research and Development,V-10,I-1,P-263-269

11) Loganathan R., Praveen Kumar S.,Grievance handling a key factor for solving issues of employees in an organization,2014,International Journal of Applied Engineering Research,V-9,I-22,P-7483-7491

12) Loganathan R., Praveen Kumar S.,Study on preference of private label brands in super and Hypermarkets,2014,International Journal of Applied Engineering Research,V-9,I-22,P-7327-7335

13) Smitha M., Praveen Kumar S.,Understanding stress and its managementamong the nurses in Chennai city,2014,International Journal of Applied Engineering Research,V-9,I-22,P-7560-7565

14) Kerinab Beenu G.H., Praveen Kumar S.,A study on the investment behavior of Chennai investors in mutual fund schemes,2014,International Journal of Applied Engineering Research,V-9,I-22,P-7520-7525

15) Loganathan R., Praveen Kumar S.,Retention strategies key for organizational productivity,2014,International Journal of Applied Engineering Research,V-9,I-22,P-7443-7447

16) Pavithra J., Ganesan M., Brindha G.,State wise analysis of microfinance sector in India,2016,International Journal of Pharmacy and Technology,V-8,I-4,P-23417-23432

17) Pavithra J., Ganesan M.,A comparative study on microfinance in India and abroad,2016,International Journal of Applied Business and Economic Research,V-14,I-8,P-5471-5476

18) Pavithra J., Ganesan M.,A study on awareness and impact of micro-financial schemes,2016,International Journal of Applied Business and Economic Research,V-14,I-8,P-5449-5460

19) Senthilmurugan P., Pavithra J.,Consumer preference towards organised retailing with reference to Big Bazaar,2014,International Journal of Applied Engineering Research,V-9,I-22,P-7469-7475

20) Senthilmurugan P., Pavithra J.,Implication of social media marketing in growing healthcare industry,2014,International Journal of Applied Engineering Research,V-9,I-22,P-7448-7456

21) Loganathan R., Pavithra J.,Consumer perception towards private label brand over other brands in super markets and hypermarkets,2014,International Journal of Applied Engineering Research,V-9,I-22,P-7355-7360

22) Kerinab Beenu G., Pavithra J.,Tradeâ€"off between liquidity and profitability in logistics industry,2014,International Journal of Applied Engineering Research,V-9,I-22,P-7398-7401

23) Kerinab Beenu G., Pavithra J.,A study on the prospective consumerâ€ $€^{\mathrm{TM}_{\mathrm{S}}}$ perception towards utility cars in Chennai city,2014,International Journal of Applied Engineering Research,V-9,I-22,P-7526-7531

24) Pavithra J., Dilli Babu P., Ambuli T.V.,A study on budgetary control at Maruti Service Masters, Chennai,2014,International Journal of Applied Business and Economic Research,V-12,I-2,P-151-161

25) Pavithra J., Dilli Babu P., Ambuli T.V.,A study on customer satisfaction of retro Garments Pvt Ltd, Chennai,2014,International Journal of Applied Business and Economic Research,V-12,I-2,P-381-391

26) Kerinab Beenu G.H., Pavithra J., Senthilmurugan P.,A study on the influence of promotional activities for TATA ARIA among consumers in Chennai,2014,International Journal of Applied Engineering Research,V-9,I-22,P-7572-7578

27) Vijayaragavan S.P.,An investigative expert that's general FBG sensors,International Journal of Mechanical Engineering and Technology,V-8,I-8,PP-1500-1505,Y-2017

28) Vijayaragavan S.P.,Equalization routing protocol for Wi-Fi sensor strategy,International Journal of Mechanical Engineering and Technology,V-8,I-8,PP-1662-1666,Y-2017

29) Karthik B., Kiran Kumar T.V.U., Vijayaragavan P., Bharath Kumaran E.,Design of a digital PLL using 0.35 $\hat{\mathrm{I}}^{1} \mathrm{/4} \mathrm{m}$ CMOS technology,Middle - East Journal of Scientific Research,V-18,I-12,PP-1803-1806,Y-2013

30) Kanniga E., Selvaramarathnam K., Sundararajan M.,Kandigital bike operating system,Middle - East Journal of Scientific Research,V

31) Jasmin M., Vigneshwaran T., Beulah Hemalatha S.,Design of power aware on chip embedded memory based FSM encoding in FPGA,International Journal of Applied Engineering Research,V-10,I-2,PP-4487-4496,Y-2015

32) Jasmin M.,Optimization techniques for low power VLSI circuits, Middle

East Journal of Scientific 
Effectiveness of Marketing Techniques Adhered Athenova Technologies

Research,V-20,I-9,PP-1082-1087,Y-2014

33) Jasmin M., Vigneswaran T.,Fuzzy controller for error control of on - Chip communication,2017 International Conference on Algorithms, Methodology, Models and Applications in Emerging Technologies, ICAMMAET 2017,V-2017-January,I-,PP-1-5,Y-2017

\section{AUTHORS PROFILE}

M. Anbarasi Research Scholar, Department of MBA Bharath Institute of Higher Education and Research, Chennai, India

Dr. S. Praveen Kumar Professor, Department of MBA

Bharath Institute of Higher Education and Research, Chennai, India. 